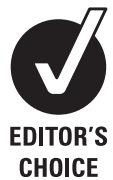

Health Services Research, ScHARR, University of Sheffield, Sheffield, UK

Correspondence to Dr Challen, 84 Whitbarrow Road, Lymm, WA13 9BA; kirstychallen@hotmail.com

Data sharing Dataset available from $\mathrm{KC}$ at kirstychallen@hotmail.com.

Accepted 6 November 2010 Published Online First 6 January 2011

\title{
Predictive scoring in non-trauma emergency patients: a scoping review
}

\author{
Kirsty Challen, Steve W Goodacre
}

\section{ABSTRACT}

This study is an inclusive scoping review of the literature relating to outcome prediction in adult non-trauma emergency patients, in order to identify the number and range of risk scores developed for acutely ill adults and to identify the outcomes these scores predict. The data source used was Medline 1950-2009. To be eligible for inclusion, papers had to detail an assessment tool, wholly or predominantly clinical, applied at the point of patient presentation to unscheduled healthcare services with outcome measures up to 30 days after presentation. Papers detailing trauma, paediatrics, purely obstetric or psychiatric presentations, tools wholly applied in a critical care setting, tools requiring an algorithm not freely available, biomarkers or tests not routinely available in an Emergency Department (ED) setting were excluded. 192 papers were reviewed. Within 17 broad disease categories, 80 inclusion criteria were used, 119 tools were assessed (25 of which were non-disease specific), and 51 outcome measures were used (30 of which were disease-specific). The areas under the receiver-operator characteristic curve (AUROCs) varied from 0.44 to 0.984 . The multiplicity of tools available presents a challenge in itself to the acute clinician. Many tools require a specific diagnosis, which is not immediately available, and the authors advocate ED development of tools for case-mix adjustment and clinical risk stratification.

\section{INTRODUCTION}

Risk scores may be used to predict which nontrauma patients presenting to an Emergency Department (ED) are likely to suffer adverse outcomes. They have two broad purposes within clinical medicine: 1 . to guide individual patient management by risk stratification, to determine best site-of-care, to place a ceiling on intensity of intervention, to decide if palliation is appropriate and to support information provided to patients and relatives; and 2. to provide case-mix adjustment for research and audit.

The use of standardised tools to affect site-ofcare decisions is most advanced in the prehospital management of trauma; a number of rules have been proposed to identify major trauma patients in need of direct transfer to a specialised trauma centre or of the presence of a full trauma team. ${ }^{1-5}$ The use of standardised alert systems in hospital has recently been advocated by the UK National Institute for Health and Clinical Excellence to identify the acutely ill patient and ensure the appropriate level of care. ${ }^{6}$

The science of risk prediction and case-mix adjustment is advanced in trauma and critical care.
A multiplicity of predictive tools exists in the critical care literature (APACHE I-IV, ${ }^{7-10}$ Mortality Probability Model I-III, ${ }^{11-13}$ Simplified Acute Physiology Score $\mathrm{I}^{14}$ and $\mathrm{II}^{15}$ ), together with refinements based on changes of those scores over time. ${ }^{16-19}$ In the UK, ${ }^{2021}$ Australasia, ${ }^{22}$ Europe $^{23-25}$ and the USA, ${ }^{26}$ various audit groups provide analysis to aid comparison between different units. In the USA and the UK, multi-site data collection (the American College of Surgeons Trauma Quality Improvement Programme ${ }^{27}$ and the Trauma Audit Research Network ${ }^{28}$ ) is ongoing to provide riskadjusted mortality ratios to assist in quality assurance at individual care providers.

The absence of similar tools in non-trauma patients causes problems in risk prediction and case-mix adjustment. Patients with delayed admission to critical care areas have higher rates of mortality than those admitted directly from the ED. ${ }^{29} 30$ Not all patients require admission to hospital or critical care, but the lack of existence of a good indicator of future deterioration may engender defensive practice and unnecessary admissions. The lack of a valid tool for case-mix adjustment also causes problems in our era of league tables. Crude mortality estimates may reflect case mix rather than quality of care, and riskadjustment may be subject to the "constant risk fallacy'. ${ }^{31}$ Failure to take these factors into account

Table 1 Previously identified severity scores for nontrauma patients searched for by name and/or common abbreviation

\begin{tabular}{ll}
\hline Altona & Alvarado \\
APACHE & Balthazar \\
Blatchford & CTAS/Canadian Triage \\
ESI/Emergency Severity & Essen \\
EWS/Early Warning Score & GCS/Glasgow Coma Scale \\
Geneva & Glasgow pancreas \\
Goldman & GRACE \\
Hardman & Manchester Triage/MTG/MTS \\
Mannheim & MEDS/Mortality in Emergency \\
& Department \\
MEEDS/Mainz Emergency & MELD \\
MPM/Mortality Probability Model & Norris \\
Peritonitis Severity Score & POSSUM \\
PURSUIT & Ranson \\
RAPS/Rapid Acute Physiology & REMS/Rapid Emergency \\
Score & Medicine \\
RISC & Score \\
ROSE & Rockall \\
SAPS/Simplified Acute Physiology & San Francisco (limited to \\
Score & Syncope) \\
SOFA & \\
TISS/Therapeutic Intervention & TIMI \\
Severity Score & \\
\hline
\end{tabular}


Table 2 Search strategy for prognostic indicators

Prognosis/OR 'Severity of Illness Index'/OR severity.mp OR risk/plus:

Acute coronary syndrome/

Aneurysm, dissecting/

Aneurysm, infected/

Aortic aneurysm/

Arsenic Poisoning/

Exp asthma/

Brain abscess/

Bronchitis, chronic/

Cadmium Poisoning/

Carbon Tetrachloride Poisoning/

Cardiomyopathy, dilated/

Central nervous system bacterial infections/

Central nervous system parasitic infections/

Chagas cardiomyopathy/

Cirrhosis.mp

Coronary aneurysm/

Dermatitis, exfoliative/

Dermatomyositis/

Exp Diabetic Ketoacidosis/

Encephalitis/

Endocarditis/

Endocarditis, subacute bacterial/

Fasciitis, Necrotizing/

Food Poisoning/

Gas Poisoning/

Heart aneurysm/

Exp Heat Exhaustion/

Heavy Metal Poisoning, Nervous System/

Hepatic encephalopathy/

Hepatitis/

Exp Hypothermia/

Intracranial aneurysm/

'Intracranial embolism and thrombosis'/

Ischemic Attack, Transient/

Liver failure/

Manganese Poisoning/

Meningitis/

Meningitis, bacterial/

Meningitis, viral/

Mercury Poisoning/

Mesenteric vascular occlusion/

Mushroom Poisoning/

Myocarditis/

Pancreatitis, acute necrotizing/

Exp peptic ulcer hemorrhage/

Peritonitis, tuberculous/

Pleuropneumonia/

Pneumonia, aspiration/

Pneumonia, pneumocystis/

Poisoning/

Pulmonary embolism/

Renal artery obstruction/

Sepsis/

Skin diseases/

Skin diseases, infectious/

Soft tissue infections/

Exp status asthmaticus/

Subarachnoid Hemorrhage/

Suppuration/

syncope, vasovagal/

Toxemia/

Ventricular dysfunction/

Ventricular dysfunction, right/ aneurysm/

aneurysm, false/

aneurysm, ruptured/

arachnoiditis/

arterial occlusive diseases/

bacteremia/

brain infarction/

bronchopneumonia/

Carbon Monoxide Poisoning/

cardiomyopathy, alcoholic/

cardiomyopathy, hypertrophic/

central nervous system fungal infections/

central nervous system viral diseases/

Ciguatera Poisoning/

confusion/

Delirium/

dermatitis herpetiformis/

Diabetic coma/

empyema, subdural/

encephalomyelitis/

endocarditis, bacterial/

epidural abscess/

Fluoride Poisoning/

fungemia/

exp gastrointestinal hemorrhage/

Heart Failure/

exp Heat Stroke/

exp hematemesis/

hepatic insufficiency/

hyperglycaemic hyperosmolar nonketotic coma/

iliac aneurysm/

intracranial embolism/

intracranial thrombosis/

Lead Poisoning/

liver failure, acute/

exp melena/

meningitis, aseptic/

meningitis, fungal/

meningoencephalitis/

Mercury Poisoning, Nervous System/

MPTP Poisoning/

myocardial infarction/

pancreatitis/

pancreatitis, alcoholic/

peritonitis/

Plant Poisoning/

pneumonia/

pneumonia, bacterial/

pneumonia, viral/

pulmonary disease, chronic obstructive/

pulmonary infarction/

Salmonella Food Poisoning/

shock, septic/

skin diseases, eczematous/

skin diseases, metabolic/

Staphylococcal Food Poisoning/

stroke/

subphrenic abscess/

Syncope/

takotsubo cardiomyopathy/

urinary tract infections/

ventricular dysfunction, left/ 
Table 3 Inclusion criteria

\begin{tabular}{|c|c|}
\hline Condition & Inclusion criteria \\
\hline AAA & $\begin{array}{l}\text { Patients undergoing endovascular repair of ruptured } A A A^{33} 34 \\
\text { Patients undergoing repair of ruptured } A A A^{35-42} \\
\text { Patients undergoing repair of ruptured infrarenal } A A A^{43}\end{array}$ \\
\hline $\begin{array}{l}\text { ACS or potential } \\
\text { ACS }\end{array}$ & $\begin{array}{l}\text { Patients with potential } \text { ACS }^{44-49} \\
\text { Patients with ACS } \\
\text { Patients with AMI }{ }^{59-65} \\
\text { Patients with NSTEMI }{ }^{69} 70 \\
\text { Patients with STEMI }{ }^{77} 71-74 \\
\text { Patients aged }>65 \text { with STEMI } \\
\text { Patients thrombolysed for STEMI } \\
\text { Patients undergoing PCI for STEMI } \\
\text { Patients admitted to inpatient telemetry } \\
\text { Patients admitted to CCU with NSTEMI } \\
\text { Patients admitted to ICU with } \text { AMI }^{79} \\
\text { Patients with chest pain after cocaine use } \\
\text { Patients being transported by helicopter with potential } \text { ACS }^{81}\end{array}$ \\
\hline Asthma/COPD & $\begin{array}{l}\text { Patients with asthma }{ }^{82-84} \\
\text { Patients admitted with COPD } \\
\text { Patients admitted to critical care with COPD/asthma }\end{array}$ \\
\hline Gl bleeding & $\begin{array}{l}\text { ED patients with } \mathrm{GI} \text { bleed }{ }^{87} \\
\text { Inpatients with upper } \mathrm{Gl} \text { bleed }{ }^{88-91} \\
\text { Inpatients undergoing } O \mathrm{GD}^{91-93} \\
\text { Inpatients undergoing } \mathrm{OGD} \text { for non-variceal bleed }{ }^{92} \\
\text { Inpatients undergoing } \mathrm{OGD} \text { for peptic ulcer } \\
\text { Inpatients undergoing } \mathrm{OGD} \text { for peptic ulcer with age }>60 \text {, } \\
\text { shock, comorbidities or } \mathrm{Hb}<10^{94} \\
\text { Inpatients with lower } \mathrm{Gl} \text { bleed }{ }^{95}\end{array}$ \\
\hline Heart failure & $\begin{array}{l}\text { Patients with acute pulmonary oedema }{ }^{96} \\
\text { Inpatients with heart failure }{ }^{97-99}\end{array}$ \\
\hline Hypothermia & Patients admitted with core temperature $<35^{100}$ \\
\hline Meningitis & Patients with bacterial meningitis ${ }^{101} 102$ \\
\hline Myxoedema & Patients with myxoedema coma ${ }^{103}$ \\
\hline Pancreatitis & $\begin{array}{l}\text { Inpatients }{ }^{104-117} \\
\text { Inpatients with 'severe' pancreatitis }{ }^{118} \\
\text { HIV + ve inpatients }\end{array}$ \\
\hline $\begin{array}{l}\text { Pneumonia } \\
\text { (non-hospital- } \\
\text { acquired) }\end{array}$ & 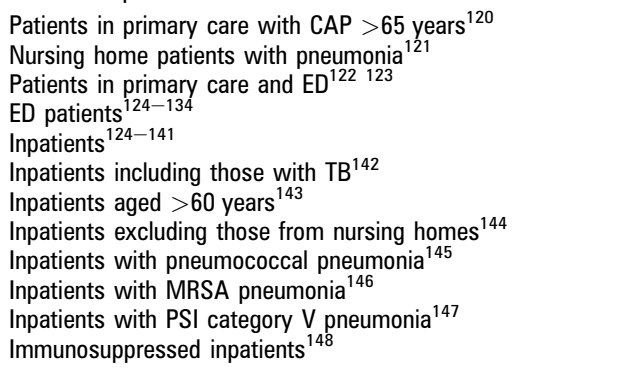 \\
\hline Poisoning & Inpatients with organophosphate poisoning ${ }^{149150}$ \\
\hline $\begin{array}{l}\text { Pulmonary } \\
\text { embolism }\end{array}$ & $\begin{array}{l}\text { Patients with a discharge diagnosis of } \mathrm{PE}^{151} \\
\text { ED patients with non-massive } \mathrm{PE}^{152} \\
\text { Patients with PE diagnosed by CT } \mathrm{CT}^{153} \\
\text { Patients undergoing CT for?PE }\end{array}$ \\
\hline Sepsis/infection & $\begin{array}{l}\text { ED patients having a blood culture taken }{ }^{154} \\
\text { ED patients with infection }{ }^{155} \\
\text { ED patients meeting SIRS criteria }{ }^{156-159} \\
\text { ED patients with severe sepsis/septic shock }{ }^{160} \\
\text { Inpatients with first episode infective endocarditis }{ }^{161} \\
\text { Inpatients with necrotising soft tissue infection } \\
\text { Patients with pyogenic liver abscess }{ }^{163} 164 \\
\text { Inpatients meeting criteria for early goal-directed therapy } \\
\text { Patients admitted to ICU via ED with sepsis }\end{array}$ \\
\hline Surgical & $\begin{array}{l}\text { Patients undergoing damage control surgery }{ }^{167} \\
\text { Patients undergoing emergency or urgent surgery } \\
\text { Patients undergoing emergency surgery for peptic ulcer }{ }^{169} \\
\text { Patients undergoing emergency surgery for colorectal } \\
\text { cancer }^{170} 171 \\
\text { Patients undergoing surgery for colonic perforation } \\
\text { Patients undergoing surgery for complications of } \\
\text { diverticulosis } \\
\text { Patients undergoing surgery for peritonitis } \\
\text { Inpatients with peritonitis secondary to hollow viscus } \\
\text { perforation }\end{array}$ \\
\hline Syncope & $\begin{array}{l}\text { ED patients with syncope }{ }^{179-181} \\
\text { ED patients with syncope or near syncope } e^{182183}\end{array}$ \\
\hline
\end{tabular}

Continued
Table 3 Continued

\begin{tabular}{|c|c|}
\hline Condition & Inclusion criteria \\
\hline TIA & $\begin{array}{l}\text { Primary care }{ }^{184} \\
\text { ED patients }^{184-187} \\
\text { Inpatients }^{188}\end{array}$ \\
\hline Unselected & $\begin{array}{l}\text { ED patients }{ }^{189} 190 \\
\text { ED patients aged }>65 \text { years }{ }^{191} \\
\text { ED patients with a non-surgical condition }{ }^{192} 193 \\
\text { ED patients seen in resuscitation area } \\
\text { Patients on MAU }{ }^{196-199} \\
\text { Patients on MAU/SAU } \\
\text { Patients admitted to critical care from the ED }{ }^{201} 202 \\
\text { Patients admitted to critical care from the ED with shock }{ }^{203}\end{array}$ \\
\hline
\end{tabular}

AAA: abdominal aortic aneurysm; ACS: acute coronary syndrome; AMI: acute myocardial infarction; CAP: community-acquired pneumonia; CCU: coronary care unit; COPD: chronic obstructive pulmonary disease; ED: emergency department; GI: gastrointestinal; ICU: intensive care unit; MAU: medical assessment unit; MRSA: methicillin-resistant staphylococcus aureus; NSTEMI: non-ST elevation myocardial infarction; OGD: oesophagogastroduodenoscopy; PCl: primary coronary intervention; PE: pulmonary embolism; PSI: pulmonary severity index; SAU: surgical assessment unit; SIRS: systemic inflammatory response syndrome; STEMI: ST elevation myocardial infarction; TB: tuberculosis.

can lead to inappropriate conclusions being drawn about the association between quality of care and mortality. ${ }^{32}$

Attempts to implement risk-prediction methods in clinical decision-making, audit and research are hampered by the substantial range and number of risk scores available. There are so many potential scores for non-trauma patients that deciding which score should be used and which variable measured presents a challenge in itself. Therefore, this study aimed to carry out a scoping review of the literature relating to outcome prediction in adult non-trauma emergency patients, in order to identify the number and range of risk scores developed for acutely ill adults and to identify the outcomes these scores predict.

\section{METHODS}

The aim was to identify papers describing assessment tools applied at the point of patient presentation to unscheduled healthcare services (excluding trauma, paediatrics and purely obstetric or psychiatric presentations) and describing short-term outcomes. A search of Medline 1950 to October week 32009 was carried out using a deliberately inclusive two-pronged strategy (tables 1 and 2). The search was deliberately designed to achieve breadth rather than depth. It was intended to determine the scope of risk scores available, rather than obtain accurate estimates of the performance of each score.

All searches were limited to English language, humans and adults. Search output was limited by title, abstract or full paper review to those papers fitting three criteria: 1 . a wholly or predominantly clinical assessment (ie, not biomarkers or specialist tests not available in the majority of EDs such as myocardial scintigraphy); 2. an adult population and 3 . an outcome measure up to 30 days after presentation. Also assessment tools requiring a specialist algorithm not freely available, or those that were applied only to patients in a critical care setting were excluded.

The following data were extracted from each article selected for inclusion: the name and/or acronym of the score, the target condition or conditions, the patient groups included in the target condition(s), the main outcomes measured and the discriminant value of the score, expressed as the area under the receiver-operator characteristic curve (AUROC) or sensitivity and specificity. The AUROC is also known as the c-statistic. It is the probability that a randomly selected patient from those with the outcome of interest will have a higher score than a randomly 
Table 4 Tools assessed

\begin{tabular}{|c|c|}
\hline Condition & Tools \\
\hline AAA & $\begin{array}{l}\text { APACHE II3 } \\
\text { Edinburgh aneurysm score } \text { s8 } 39^{43} \\
\text { Glasgow aneurysm score } \text { scor }^{38-40} \\
\text { Hardman }^{33-36} 38-4042 \\
\text { Modified Hardman }^{35} \\
\text { POSSUM }^{43} \\
\text { RAAA-POSSUM } \\
\text { V-POSSUM }^{42}\end{array}$ \\
\hline ACS or potential ACS & 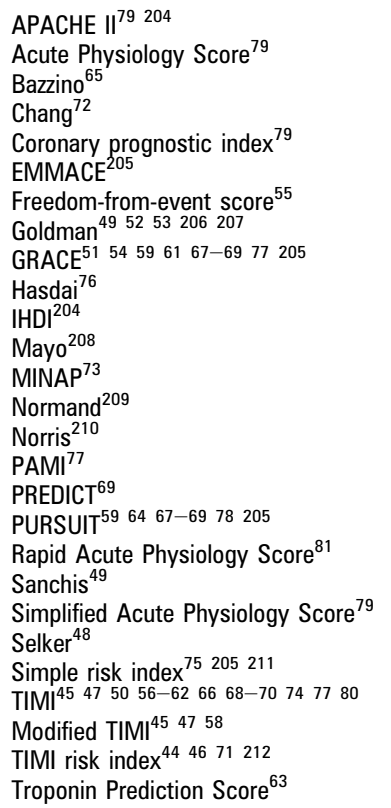 \\
\hline Asthma/COPD & $\begin{array}{l}\text { Acute asthma index } \\
\text { APACHE II Acute physiology } \\
\text { BAP- } 65^{85} \\
\text { CAPS }^{86} \\
\text { National asthma guidelines } \\
\text { Rodrigo }^{83}\end{array}$ \\
\hline Gl bleed & $\begin{array}{l}\text { Blatchford }{ }^{91} 92194213 \\
\text { Modified Blatchford }^{195} \\
\text { BLEED }^{87} \\
\text { Bordley }^{88} \\
\text { Rockall }^{89} 94 \\
\text { Rockall (clinical component) }^{90-93213} \\
\text { Strate }^{95}\end{array}$ \\
\hline Heart failure & $\begin{array}{l}\text { ADHERE decision rule } \\
\text { ADHERE logistic regression }^{97} \\
\text { Brigham }^{97} \\
\text { EFFECT }^{97} 99 \\
\text { Le Conte }^{96} \\
\text { Pulmonary edema prognostic score }\end{array}$ \\
\hline Hypothermia & Elbaz $^{100}$ \\
\hline Meningitis & $\begin{array}{l}\text { Aronin }^{101} \\
\text { Weisfelt }^{102}\end{array}$ \\
\hline Myxoedema & SOFA 103 \\
\hline Pancreatitis & 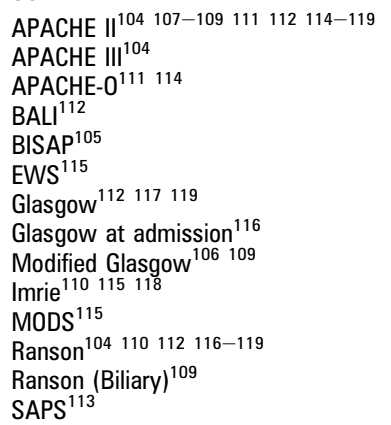 \\
\hline
\end{tabular}

Continued
Table 4 Continued

\begin{tabular}{|c|c|}
\hline Condition & Tools \\
\hline Pneumonia & 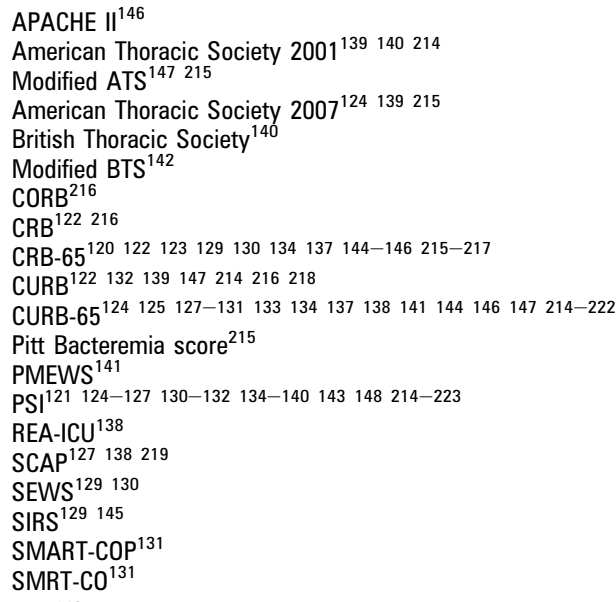 \\
\hline Poisoning & $\begin{array}{l}\text { GCS }^{149} \\
\text { Modified APACHE } \\
\text { Poison severity score }\end{array}$ \\
\hline Pulmonary embolism & $\begin{array}{l}\text { Aujesky }{ }^{151} 152 \\
\text { PESI }^{153}\end{array}$ \\
\hline Sepsis/infection & $\begin{array}{l}\text { APACHE } \|^{162} 163165 \\
\text { APS }^{161} \\
\text { CURB-65 }^{155} \\
\text { MEDS }^{154-156} \quad 158-160165166 \\
\text { MEWS }^{158} \\
\text { MPMO }^{165} \\
\text { REMS }^{155} \\
\text { SAPS } \|^{157} 164165 \\
\text { SOFA }^{157}\end{array}$ \\
\hline Surgical & 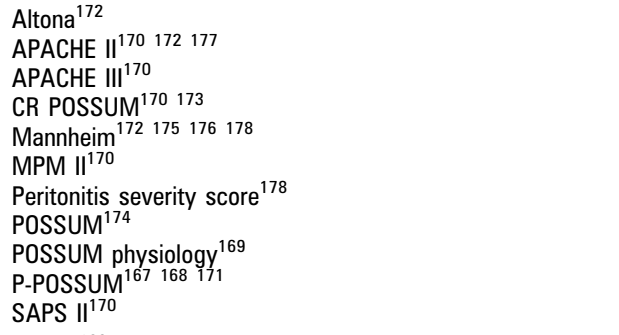 \\
\hline Syncope & $\begin{array}{l}\text { EGSYS }^{180} \\
\text { OESIL }^{181} \\
\text { San Francisco }\end{array}$ \\
\hline TIA & $\begin{array}{l}\text { ABCD } 185186188 \\
\text { ABCD2 }^{184} 187\end{array}$ \\
\hline Unselected & 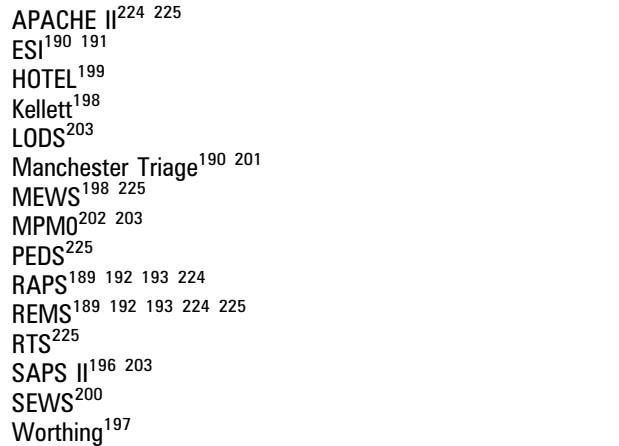 \\
\hline
\end{tabular}

$\mathrm{AAA}$, abdominal aortic aneurysm; ACS, acute coronary syndrome; COPD, chronic obstructive pulmonary disease; $\mathrm{Gl}$, gastrointestinal; TIA, transient ischaemic attack.

selected patient without the outcome of interest. A score with a c-statistic of 0.5 or less has no value for discriminating which patients will suffer the outcome of interest. Similarly, a dichotomised score for which the sensitivity and specificity add up to $100 \%$ or less has no discriminatory value.

It was not planned to synthesise data, but to present descriptive data outlining the breadth of scores available for 
Table 5 Outcome measures

\begin{tabular}{|c|c|}
\hline Condition & Outcome measures \\
\hline AAA & $\begin{array}{l}\text { 'Immediate' postoperative death }{ }^{40} \\
30 / 7 \text { death }^{33} \\
\text { Inpatient death }{ }^{34-36} 384243 \\
\text { Inpatient or } 30 / 7 \text { death }{ }^{39} 41\end{array}$ \\
\hline $\begin{array}{l}\text { ACS or potential } \\
\text { ACS }\end{array}$ & 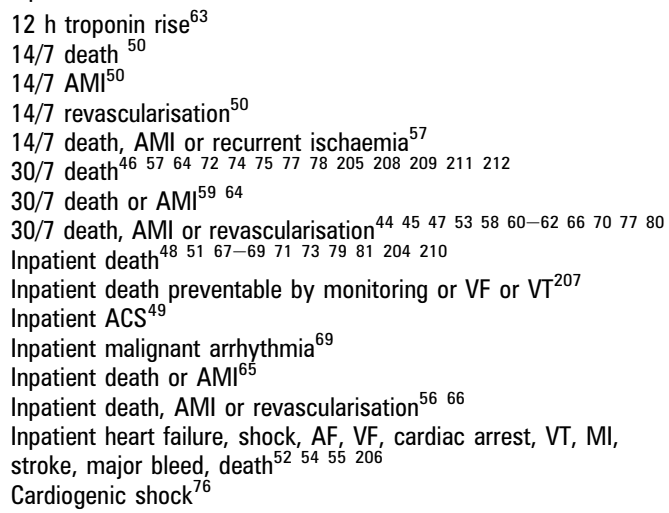 \\
\hline Asthma/COPD & $\begin{array}{l}\text { Poor treatment respons }{ }^{84} \\
\text { Hospitalisation }{ }^{82} 83 \\
\text { Requirement for mechanical ventilation } \\
\text { Inpatient death } \\
\text { I5 }_{86}\end{array}$ \\
\hline Gl bleed & $\begin{array}{l}30 / 7 \text { rebleed }^{92} 94213 \\
30 / 7 \text { death }^{94} \\
\text { Inpatient death }^{89} 9293 \\
\text { Inpatient rebleed } \\
\text { Inpatient intervention or death }^{91} \\
\text { Inpatient rebleed or death } \\
\text { Inpatient rebleed, surgery or death } \\
\text { Requiring transfusion, surgery or endoscopic intervention }{ }^{194} \\
\text { Requiring }>2 \text { unit transfusion, }>20 \% \text { fall in haematocrit, rebleed } \\
>24 \mathrm{~h}^{95} \\
\text { Requiring endoscopic intervention } \\
\text { High risk stigmata at } 0 \mathrm{GD}^{195}\end{array}$ \\
\hline Heart failure & $\begin{array}{l}30 / 7 \text { death }^{99} \\
\text { Inpatient death } \\
\text { Inpatient death or life-threatening condition }{ }^{97}\end{array}$ \\
\hline Hypothermia & Inpatient death ${ }^{100}$ \\
\hline Meningitis & $\begin{array}{l}\text { Inpatient death } \\
\text { Glasgow Outcome Score } 1-4^{102}\end{array}$ \\
\hline Myxoedema & Inpatient death ${ }^{103}$ \\
\hline Pancreatitis & $\begin{array}{l}\text { Inpatient death }{ }^{105} 106112113115117118 \\
\text { Atlanta severity criteria }^{104} 108114115 \\
\text { Admission to critical care }^{107} 117 \\
\text { Admission to critical care }>1 / 7^{109} \\
\text { Admission to critical care }>5 / 7^{116} \\
\text { Admission to critical care, necrosis or death } \\
\text { Admission to critical care, local complications, surgery or death } \\
\text { Severe complications } \\
\text { Infection (bacteraemia/infected necrosis) }^{117}\end{array}$ \\
\hline \multirow[t]{2}{*}{ Pneumonia } & $\begin{array}{l}\text { 2/7 death }{ }^{136} \\
14 / 7 \text { death }^{215} \\
\text { 28/7 death } \\
\text { 30/7 death } \\
\text { 220-223 }\end{array}$ \\
\hline & $\begin{array}{l}\text { Inpatient death } 124135139142145148214 \\
\text { Hospitalisation } 121141 \\
\text { Complicated effusion or empyema } \\
\text { Severe sepsis } \\
\text { Critical care admission } \\
\text { Critical care admission or death } 127132134219 \\
\text { Critical care admission in } 1-3 / 7^{138}\end{array}$ \\
\hline Poisoning & $\begin{array}{l}\text { Inpatient death }{ }^{149} \\
\text { Requirement for endotracheal intubation }{ }^{150}\end{array}$ \\
\hline $\begin{array}{l}\text { Pulmonary } \\
\text { embolism }\end{array}$ & $\begin{array}{l}\text { 30/7 death } \\
\text { Inpatient death } \\
\text { His2 } \\
\text { Haemodynamic instability } \\
{ }^{152}\end{array}$ \\
\hline Sepsis/infection & $\begin{array}{l}\text { 5/7 death } \\
28 / 7 \text { death }^{155} 156158166 \\
\text { 30/7 death } \\
\text { Inpatient death }^{159} 159 \\
160-165\end{array}$ \\
\hline
\end{tabular}

Continued
Table 5 Continued

\begin{tabular}{|c|c|}
\hline Condition & Outcome measures \\
\hline Surgical & $\begin{array}{l}\text { 30/7 death }{ }^{168} 173 \\
\text { Inpatient death } \\
\text { Complication }^{169}\end{array}$ \\
\hline Syncope & $\begin{array}{l}\text { 7/7 serious outcome }{ }^{179} 182183 \\
\text { Adverse cardiac outcome }{ }^{181} \\
\text { Final diagnosis cardiac syncope }{ }^{180}\end{array}$ \\
\hline TIA & $\begin{array}{l}2 / 7 \mathrm{CVA}^{184} \\
7 / 7 \mathrm{CVA}^{184-188} \\
30 / 7 \mathrm{CVA}^{186} 188\end{array}$ \\
\hline Unselected & $\begin{array}{l}\text { Hospital admission }{ }^{190} 191 \\
\text { Admission to } \text { critical care }^{201} \\
24 \mathrm{~h} \text { death } \\
7 / 7 \text { death or ICU admission } \\
14 / 7 \text { death } \\
\text { 224 } \\
\text { 30/7 death } \\
\text { Inpatient death }^{192} \\
\text { I89 } 192193196197200202203\end{array}$ \\
\hline
\end{tabular}

AAA, abdominal aortic aneurysm; ACS, acute coronary syndrome; AMI, acute myocardia infarction; COPD, chronic obstructive pulmonary disease; CVA, cerebrovascular accident; ICU, intensive care unit; MI, myocardial infarction; OGD, oesophagogastroduodenoscopy; TIA, transient ischaemic attack; VF, ventricular fibrillation; VT, ventricular tachycardia.

different conditions, the outcomes measured and the range of AUROC values reported.

\section{RESULTS}

The initial searches identified 14659 (method 1) and 46605 (method 2) titles. A significant number of titles were identified by more than one search. Six hundred and eighty-two (method 1) and 1661 (method 2) abstracts were screened and 192 papers deemed to fit the inclusion criteria.

Scoring systems were available for 17 broad conditions. Within these 17 conditions, 80 different inclusion criteria were used (table 3).

One-hundred and nineteen tools were assessed (table 4). Of these, 25 were generic (non-disease-specific). A number of tools were assessed in multiple disease categories.

Fifty-one different outcome measures were used (table 5). Of these, 30 were disease-specific.

A variety of different measures were used to report score performance. Of 247 analyses using death as an outcome, 190 reported an AUROC, of which 69 reported an AUROC greater than 0.8 . Of 215 analyses not including death as an outcome, 151 reported an AUROC, of which 30 reported an AUROC greater than 0.8. A number of studies (22) used the same dataset to compare the predictive value of a single tool for different outcomes (table 6). For comparison, the lowest AUROC in the study was 0.44 (PIMI for predicting hospital death in patients with acute myocardial infarction ${ }^{204}$ ) and the highest was 0.984 (APACHE II for predicting hospital death in patients with peritonitis ${ }^{177}$ ). It is generally accepted that an AUROC of over 0.8 represents good discriminatory capacity. ${ }^{226}$

Studies were variously purely derivation, mixed derivation and validation, external validation and secondary analysis of other datasets (including disease registries) (table 7).

\section{DISCUSSION}

A wide variation in the patient groups to which scoring systems are applied has been demonstrated, and an equally wide variation in patient outcomes considered relevant. The sheer number of available tools makes it impossible for the working clinician to use more than a few in daily practice. The discriminant value of the scores, expressed as an AUROC or sensitivity and specificity, often varies between studies and is poor in many cases, suggesting the score will have limited value in practice. Furthermore, most scores 
Table 6 Studies with comparison of different outcome measures

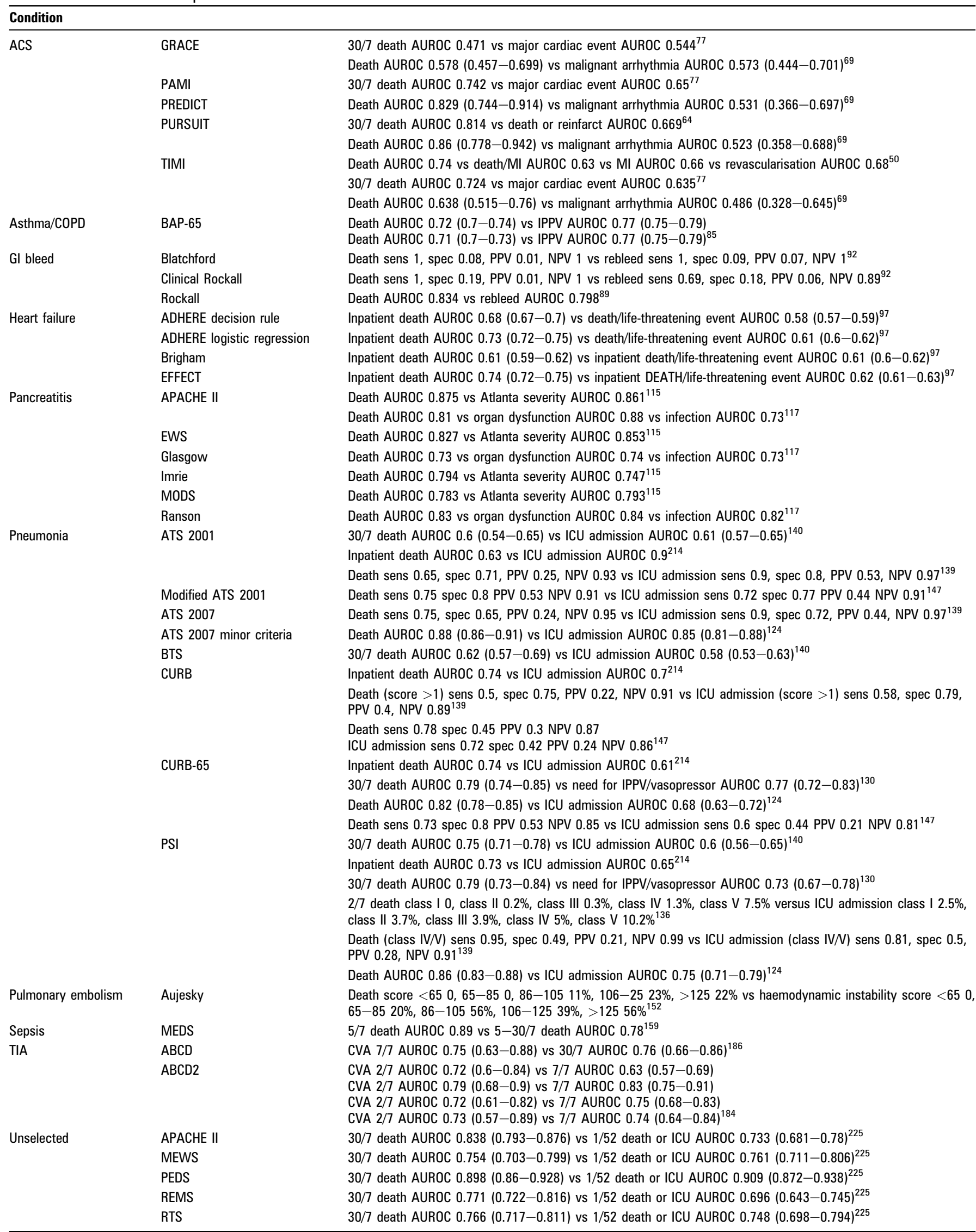

ACS, acute coronary syndrome; AUROC, area under ROC curve; COPD, chronic obstructive pulmonary disease; GI, gastrointestinal; ICU, intensive care unit; IPPV, intermittent positive pressure ventilation; Ml, myocardial infarction; NPV, negative predictive value; PPV, positive predictive value; sens, sensitivity; spec, specificity; TIA, transient ischaemic attack. 
Table 7 Source of datasets

\begin{tabular}{|c|c|}
\hline Studies reporting purely derivation sets & $\begin{array}{l}\text { AAA }^{3538} \\
\text { ACS }^{6573} \\
\text { Heart failure }^{9698} \\
\text { Hypothermia }^{100} \\
\text { Unselected }^{193225}\end{array}$ \\
\hline $\begin{array}{l}\text { Studies reporting derivation and } \\
\text { validation sets }\end{array}$ & $\begin{array}{l}\text { ACS }^{38} 4261208 \\
\text { Asthma/COPD }^{83} 8586 \\
\text { Gl bleed }^{88} 95 \\
\text { Heart failure }^{99} \\
\text { Meningitis }^{101} 102 \\
\text { Pneumonia }^{127} 131 \quad 146148 \quad 151 \\
\text { Pulmonary embolism }^{151} \\
\text { Sepsis }^{154} \\
\text { Syncope }^{180} \\
\text { Unselected }^{215-217}\end{array}$ \\
\hline Studies providing external validation & 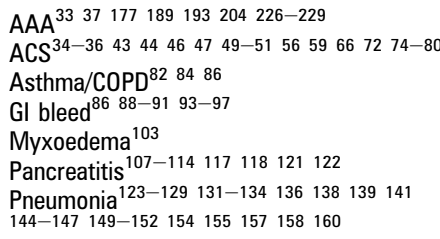 \\
\hline & 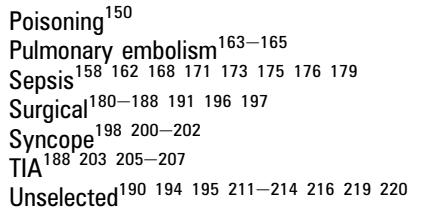 \\
\hline $\begin{array}{l}\text { Studies with secondary analysis } \\
\text { of data collected for another } \\
\text { purpose as derivation set }\end{array}$ & $\begin{array}{l}\text { ACS }^{4045} 5354697173 \\
\text { Pancreatitis }^{112}\end{array}$ \\
\hline $\begin{array}{l}\text { Studies with secondary analysis } \\
\text { of data collected for another } \\
\text { purpose as validation set }\end{array}$ & 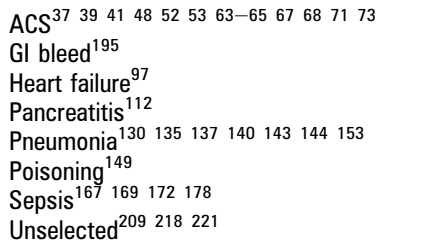 \\
\hline
\end{tabular}

AAA, abdominal aortic aneurysm; ACS, acute coronary syndrome; COPD, chronic obstructive pulmonary disease; $\mathrm{GI}$, gastrointestinal; TIA, transient ischaemic attack.

have only been tested in the population in which they were developed. This will tend to overestimate the discriminatory value and further reduce the value of the scores in practice.

The authors are not aware of any previous systematic reviews that have attempted to characterise the full scope of risk scores available for non-trauma patients. Although there is obviously a huge amount of primary data relating to risk scores, there have been few attempts to systematically evaluate these data and draw broader conclusions for clinical practice. Indeed, one of the characteristics of the literature relating to risk scores is that each risk score seems to be developed de novo with very little reference to previous studies or other scores. This may reflect the tendency for studies developing risk scores to be secondary analyses of existing datasets rather than studies undertaken for the primary purpose of developing a risk score. The present review suggests that further unfocussed primary research is unlikely to clarify the situation. Instead, future studies of risk scores should aim to build on existing data and be designed specifically to develop an optimal risk score.

The study is limited by the structure and the lack of information in many included papers. Few were precise about the timing of the assessment, leaving potential for lead-time bias. The majority focused on hospital-specific outcomes, and it is often unclear to what extent patient-relevant out-of-hospital outcomes have been investigated. The often restricted nature of patient sets (eg, requiring consultant radiologist confirmation for the diagnosis of pneumonia) limits the generalisability of many of the results to the day-to-day ED population where formal diagnosis is often not known initially; only four papers could be identified assessing a truly unselected group of ED patients. $^{189190192193}$

Although a number of reviews have analysed the performance of systems identifying high-risk inpatients, ${ }^{227-229}$ the authors are unaware of any previous review of similar tools available to the ED clinician.

It is apparent that one outcome measure does not fit all; in the limited literature assessing the performance of the same tool for two different outcomes, the results rarely matched. Clinicians must therefore examine their practice and decide which outcomes are relevant to their patients and situation. It is highly unlikely that a tool developed for case-mix adjustment will perform equally well at clinical risk stratification; currently the ED community lacks a tool for either and both should be developed. It is likely, given the heterogeneity of ED patients, that it will be challenging to develop a single overall predictive tool; it may be that a variable of presenting complaint (along the lines of APACHE) will be required in such a tool for it to be of benefit in simplifying risk prediction for the practising Emergency Physician.

Funding SG is an employee of the University of Sheffield. KC is funded by a Medical Research Council PhD studentship. Neither body had any role in study design; in the collection, analysis, and interpretation of data; in the writing of the report; or in the decision to submit the article for publication.

Competing interests All authors have completed the Unified Competing Interest form at http://www.icmje.org/coi_disclosure.pdf (available on request from the corresponding author) and declare that (1) no authors have support from any commercial company for the submitted work; (2) no authors have relationships with any commercial company that might have an interest in the submitted work in the previous 3 years; (3) their spouses, partners, or children have no financial relationships that may be relevant to the submitted work; and (4) no authors have non-financial interests that may be relevant to the submitted work.

Contributors KC and SG jointly conceived the study, analysed the data and drafted the manuscript. KC carried out the literature search and is the guarantor. Both authors had full access to all of the data in the study and can take responsibility for the integrity of the data and the accuracy of the data analysis.

Provenance and peer review Not commissioned; externally peer reviewed.

\section{REFERENCES}

1. Gray A, Goyder E, Goodacre $S$, et al. Trauma triage: a comparison of CRAMS and TRTS in a UK population. Injury 1997:28:97-101.

2. Baxt WG, Jones $G$, Fortlaget $D$. The trauma triage rule: a new, resource-based approach to the prehospital identification of major trauma victims. Ann Emerg Med 1990;19:1401-6.

3. Bond R, Kortbeek J, Preshaw R. Field trauma triage: combining mechanism of injury with the prehospital index for an improved trauma triage tool. J Trauma 1997;:443:283-7.

4. Emerman CL, Shade B, Kubincanek J. Comparative performance of the Baxt Trauma triage rule. Am J Emerg Med 1992;10:294-7.

5. Gilpin D, Nelson P. Revised trauma score: a triage tool in the accident and emergency department. Injury 1991;22:35-7.

6. NICE Short Clinical Guidelines Technical Team. Acutely ill patients in hospital: recognition of and response to acute illness in adults in hospital. London: National Institute for Health and Clinical Excellence, 2006.

7. Knaus W, Zimmerman J, Wagner D, et al. Apache: acute physiology and chronic health evaluation; a physiologically based classification system. Crit Care Med 1981:9:591.

8. Knaus WA, Draper EA, Wagner D, et al. APACHE II: a severity of disease classification system. Crit Care Med 1985;13:818-29.

9. Knaus W, Wagner D, Draper E, et al. The APACHE III prognostic system. Risk prediction of hospital mortality for critically ill hospitalized adults. Chest 1991;100:1619-36

10. Zimmerman JE, Kramer AA, McNair DS, et al. Acute Physiology and Chronic Health Evaluation (APACHE) IV: Hospital mortality assessment for today's critically ill patients. Crit Care Med 2006:34:1297-310.

11. Lemeshow S, Teres D, Pastides $\mathrm{H}$, et al. A method for predicting survival and mortality of ICU patients using objectively derived weights. Crit Care Med 1985;13:519-25.

12. Lemeshow $\mathbf{S}$, Teres $\mathrm{D}$, Klar J, et al. Mortality probability models (MPM II) based on an international cohort of intensive care unit patients. JAMA 1993;270:2478-86. 
13. Higgins TL, Teres D, Copes WS, et al. Assessing contemporary intensive care unit outcome: an updated Mortality Probability Admission Model (MPMO-III). Crit Care Med 2007:35:827-35.

14. Le Gall J-R, Loirat P, Alperovitch A, et al. A simplified acute physiology score for ICU patients. Crit Care Med 1984;12:975-7.

15. Le Gall J, Lemeshow S, Saulnier F. A new simplified acute physiologic score (SAPS II) based on a European/North American multicenter study. JAMA 1993;270:2957-63

16. Chang R, Jacobs $S$, Lee B. Predicting outcome among intensive care unit patients using computerised trend analysis of daily Apache II scores corrected for organ system failure. Intens Care Med 1988;14:558-66.

17. Ferreira FL, Peres Bota D, Bross A, et al. Serial evaluation of the SOFA score to predict outcome in critically ill patients. JAMA 2001;286:1754-8.

18. Ho KM, Dobb GJ, Knuiman M, et al. A comparison of admission and worst 24-hour Acute Physiology and Chronic Health Evaluation II scores in predicting hospital mortality: a retrospective cohort study. Critical Care 2006;10:R4

19. Rogers J, Fuller HD. Use of daily Acute Physiology and Chronic Health Evaluation (APACHE) II scores to predict individual patient survival rate. Crit Care Med 1994;22:1402-5

20. Rowan K, Kerr J, Major E, et al. Intensive Care Society's APACHE II study in Britain and Ireland-II: outcome comparisons of intensive care units after adjustment for case mix by the American APACHE II method. BMJ 1993;307:977-81.

21. Scottish Intensive Care Society Audit Group. Audit of critical care in Scotland 2009. Edinburgh: NHS National Services Scotland, 2009

22. Stow $\mathbf{P}$, Hart G, Higlett T, et al. Development and implementation of a high-quality clinical database: the Australian and New Zealand Intensive Care Society Adult Patient Database. J Crit Care 2006;21:133-41.

23. Brazzi L, Apolone G, Liberati A. Risultati preliminari di uno studio multicentrico sui profili di cura e sull'outcome di pazienti ricoverati in reparti di terapia intensiva. Minerva Anestesiol 1992;58:927-9.

24. Peelen L, de Keizer NF, Peek N, et al. The influence of volume and intensive care unit organization on hospital mortality in patients admitted with severe sepsis: a retrospective multicentre cohort study. Crit Care 2007;11:R40.

25. Vázquez Mata G, Jiménez Quintana M, Rivera Fernández R, et al. Objetivación de la gravedad mediante el sistema APACHE-III aplicado en España. Med Clin 2001:117:446-51.

26. Cook SF, Visscher WA, Hobbs CL, et al. Results from a pilot validity study of a new observational database. Crit Care Med 2002;30:2765-70.

27. Demetriades D, Martin M, Salim A, et al. The effect of trauma center designation and trauma volume on outcome in specific severe injuries. Ann Surg 2005;242:512-19.

28. Lecky F, Woodford M, Bouamra 0, et al. Lack of change in trauma care in England and Wales since 1994. Emerg Med J 2002;19:520-3.

29. Parkhe M, Myles PS, Leach DS, et al. Outcome of emergency department patients with delayed admission to an intensive care unit. Emerg Med Australas 2002;14:50-7

30. McQuillan P, Pilkington S, Allan A, et al. Confidential inquiry into quality of care before admission to intensive care. BMJ 1998;316:1853-8

31. Nicholl J. Case-mix adjustment in non-randomised observational evaluations: the constant risk fallacy. J Epidemiol Commun Health 2007:61:1010-13.

32. Mohammed MA, Deeks JJ, Girling A, et al. Evidence of methodological bias in hospital standardised mortality ratios: retrospective database study of English hospitals. BMJ 2009;338:b780.

33. Karkos CD, Karamanos D, Papazoglou KO, et al. Usefulness of the Hardman index in predicting outcome after endovascular repair of ruptured abdominal aortic aneurysms. J Vasc Surg 2008:48:788-94.

34. Sharif MA, Lee B, Makar RR, et al. Role of the Hardman Index in predicting mortality for open and endovascular repair of ruptured abdominal aortic aneurysm. $J$ Endovasc Ther 2007:14:528-35.

35. Calderwood R, Halka T, Haji-Michael P, et al. Ruptured abdominal aortic aneurysm: is it possible to predict outcome? Int Angiol 2004:23:47-53.

36. Prance S, Wilson Y, Cosgrove C, et al. Ruptured abdominal aortic aneurysms: selecting patients for surgery. Eur J Vasc Endovasc Surg 1999:17:129-32.

37. Tambyraja A, Fraser S, Murie J, et al. Validity of the Glasgow Aneurysm Score and the Hardman Index in predicting outcome after ruptured abdominal aortic aneurysm repair. Br J Surg 2005;92:573-3.

38. Tambyraja A, Murie J, Chalmers R. Predictors of outcome after abdominal aortic aneurysm rupture: Edinburgh ruptured aneurysm score. World J Surg 2007:31:2243-7.

39. Tambyraja AL, Lee AJ, Murie JA, et al. Prognostic scoring in ruptured abdominal aortic aneurysm: a prospective evaluation. J Vasc Surg 2008;47:282-6.

40. Leo E, Biancari F, Nesi F, et al. Risk-scoring methods in predicting the immediate outcome after emergency open repair of ruptured abdominal aortic aneurysm. $A m \mathrm{~J}$ Surg 2006:192:19-23

41. Harris JR, Forbes TL, Steiner SH, et al. Risk-adjusted analysis of early mortality after ruptured abdominal aortic aneurysm repair. J Vasc Surg 2007:42:387-91.

42. Neary W, Crow P, Foy C, et al. Comparison of POSSUM scoring and the Hardman Index in selection of patients for repair of ruptured abdominal aortic aneurysm. $\mathrm{Br} J$ Surg 2003:90:421-5

43. Lazarides MK, Arvanitis DP, Drista $\mathrm{H}$, et al. Scores do not predict the outcome of ruptured infrarenal aortic aneurysms. Ann Vasc Surg 1997;11:155-8.
44. García-Almagro FJ, Gimeno JR, Villegas $\mathrm{M}$, et al. Prognostic value of the Thrombolysis in Myocardial Infarction risk score in a unselected population with chest pain. Construction of a new predictive model. Am J Emerg Med 2008:26:439-45.

45. Conway Morris A, Caesar D, Gray S, et al. TIMl risk score accurately risk stratifies patients with undifferentiated chest pain presenting to an emergency department. Heart 2006;92:1333-4.

46. Ilkhanoff L, O'Donnell CJ, Camargo CA, et al. Usefulness of the TIMI Risk Index in predicting short- and long-term mortality in patients with acute coronary syndromes. Am J Cardiol 2005;96:773-7.

47. Jaffery Z, Hudson MP, Jacobsen G, et al. Modified Thrombolysis in Myocardial Infarction (TIMI) risk score to risk stratify patients in the emergency department with possible acute coronary syndrome. J Thromb Thrombolysis 2007;24:137-44.

48. Selker HP, Griffith JL, D'Agostino RB. A time-insensitive predictive instrument for acute myocardial infarction mortality: a multicenter study. Med Care 1991;29:1196-211.

49. Manini AF, Dannemann N, Brown DF, et al. Limitations of risk score models in patients with acute chest pain. Am J Emerg Med 2009;27:43-8.

50. Antman E, Cohen M, Bernink P. The TIMI risk score for unstable angina/non-ST elevation $\mathrm{Ml}$. a method for prognostication and therapeutic decision making. JAMA 2000;284:835-42.

51. Elbarouni B, Goodman SG, Yan RT, et al. Validation of the Global Registry of Acute Coronary Event (GRACE) risk score for in-hospital mortality in patients with acute coronary syndrome in Canada. Am Heart $J$ 2009;158:392-9.

52. Goldman L, Cook EF, Johnson PA, et al. Prediction of the need for intensive care in patients who come to emergency departments with acute chest pain. $N$ Engl J Med 1996;334:1498-504.

53. Limkakeng A, Gilbler WB, Pollack C, et al. Combination of Goldman risk and initial cardiac troponin I for emergency department chest pain patient risk stratification. Acad Emerg Med 2001;8:696-702.

54. Sinclair $\mathbf{H}$, Paterson $\mathrm{M}$, Walker $\mathrm{S}$, et al. predicting outcome in patients with acute coronary syndrome: evaluation of b-type natriuretic peptide and the global registry of acute coronary events (GRACE) Risk score. Scott Med J 2007:52:8-13

55. Brieger D, Fox K, FitzGerald G, et al. Predicting freedom from clinical events in non-ST elevation acute coronary syndromes: the Global Registry of Acute Coronary Events. Heart 2009:95:888-94.

56. Soiza $\mathbf{R}$, Leslie S, Williamson P. Risk stratification in acute coronary syndromes-does the TIMI risk score work in unselected cases? Q J Med 2006:99:81-7.

57. Foussas SG, Zairis MN, Lyras AG, et al. Early prognostic usefulness of c-reactive protein added to the thrombolysis in myocardial infarction risk score in acute coronary syndromes. Am J Cardiol 2005:96:533-7.

58. Body R, Carley S, McDowell G, et al. Can a modified thrombolysis in myocardial infarction risk score outperform the original for risk stratifying emergency department patients with chest pain? Emerg Med J 2009:26:95-9.

59. de Araujo Goncalves P, Ferreira J, Aguiar C, et al. TIMI, PURSUIT, and GRACE risk scores: sustained prognostic value and interaction with revascularization in NSTE-ACS. Eur Heart J 2005;26:865-72.

60. Karounos M, Chang AM, Robey JL, et al. TIMl risk score: does it work equally well in both males and females? Emerg Med J 2007:24:471-4.

61. Lyon R, Morris AC, Caesar D, et al. Chest pain presenting to the Emergency Department-to stratify risk with GRACE or TIMI? Resuscitation 2007;74:90-3.

62. Pollack CV, Sites FD, Shofer FS, et al. Application of the TIMl risk score for unstable angina and non-ST elevation acute coronary syndrome to an unselected emergency department chest pain population. Acad Emerg Med 2006:13:13-18.

63. Januzzi JL, Newby LK, Murphy SA, et al. Predicting a late positive serum troponin in initially troponin-negative patients with non-ST-elevation acute coronary syndrome: Clinical predictors and validated risk score results from the TIMI IIIB and GUSTO IIA studies. Am Heart J 2006;151:360-6.

64. Boersma E, Peiper KS, Steyerberg E, et al. Predictors of outcome in patients with acute coronary syndromes without persistent ST-segment elevation: result from an international trial of 9461 patients. Circulation 2000;101:2557-67.

65. Bazzino 0, Díaz R, Tajer C, et al. Clinical predictors of in-hospital prognosis in unstable angina: ECLA 3. Am Heart J 1999:137:322-31.

66. Campbell CF, Chang AM, Sease KL, et al. Combining thrombolysis in myocardial infarction risk score and clear-cut alternative diagnosis for chest pain risk stratification. Am J Emerg Med 2009:27:37-42.

67. Yan AT, Jong P, Yan RT, et al. Clinical trial-derived risk model may not generalize to real-world patients with acute coronary syndrome. Am Heart $J$ 2004; 148:1020-7.

68. Yan AT, Yan RT, Tan M, et al. Risk scores for risk stratification in acute coronary syndromes: useful but simpler is not necessarily better. Eur Heart $J$ 2007;28:1072-8.

69. Rahimi K, Watzlawek S, Thiele $\mathrm{H}$, et al. Incidence, time course, and predictors of early malignant ventricular arrhythmias after non-ST-segment elevation myocardia infarction in patients with early invasive treatment. Eur Heart J 2006;27:1706-11.

70. Samaha FF, Kimmel SE, Kizer JR, et al. Usefulness of the TIMI risk score in predicting both short- and long-term outcomes in the Veterans Affairs Non-OWave Myocardial Infarction Strategies In-Hospital (VANOWISH) Trial. Am J Cardiol 2002;90:922-6

71. Wiviott SD, Morrow DA, Frederick PD, et al. performance of the thrombolysis in myocardial infarction risk index in the national registry of myocardial infarction-3 
and -4: a simple index that predicts mortality in ST-segment elevation myocardial infarction. J Am Coll Cardiol 2004;44:783-9.

72. Chang W-C, Kaul P, Fu Y, et al. Forecasting mortality: dynamic assessment of risk in ST-segment elevation acute myocardial infarction. Eur Heart J 2006;27:419-26.

73. Gale C, Manda S, Batin P, et al. Predictors of in-hospital mortality for patients admitted with ST-elevation myocardial infarction: a real-world study using the Myocardial Infarction National Audit Project (MINAP) database. Heart 2008;94:1407-12.

74. Morrow DA, Antman EM, Charlesworth A, et al. TIMI risk score for ST-elevation myocardial infarction: a convenient, bedside, clinical score for risk assessment at presentation. Circulation 2000;102:2031-7.

75. Rathore SS, Weinfurt KP, Gross CP, et al. Validity of a simple ST-elevation acute myocardial infarction risk index: are randomized trial prognostic estimates generalizable to elderly patients? Circulation 2003;107:811-16.

76. Hasdai D, Califf RM, Thompson TD, et al. Predictors of cardiogenic shock after thrombolytic therapy for acute myocardial infarction. J Am Coll Cardiol 2000:35:136-43.

77. Lev El, Kornowski R, Vaknin-Assa $\mathrm{H}$, et al. Comparison of the predictive value of four different risk scores for outcomes of patients with ST-elevation acute myocardial infarction undergoing primary percutaneous coronary intervention. Am J Cardiol 2008;102:6-11.

78. Brilakis ES, Wright RS, Kopecky SL, et al. Association of the PURSUIT risk score with predischarge ejection fraction, angiographic severity of coronary artery disease, and mortality in a nonselected, community-based population with nonST-elevation acute myocardial infarction. Am Heart J 2003:146:811-18.

79. Moreau R, Soupison T, Vauquelin P, et al. Comparison of two simplified severity scores (SAPS and APACHE II) for patients with acute myocardial infarction. Crit Care Med 1989:17:409-13.

80. Chase M, Brown AM, Robey JL, et al. Application of the TIMI risk score in ED patients with cocaine-associated chest pain. Am J Emerg Med 2007;25:1015-18.

81. Rhee KJ, MacKenzie JR, Burney RE, et al. Rapid acute physiology scoring in transport systems. Crit Care Med 1990;18:1119-23.

82. Kelly A-M, Kerr D, Powell C. Is severity assessment after one hour of treatment better for predicting the need for admission in acute asthma? Respir Med 2004;98:777-81.

83. Rodrigo G, Rodrigo C. A new index for early prediction of hospitalization in patients with acute asthma. Am J Emerg Med 1997;15:8-13.

84. Rodrigo G, Rodrigo C. Early prediction of poor response in acute asthma patients in the emergency department. Chest 1998:114:1016-21.

85. Tabak YP, Sun X, Johannes RS, et al. Mortality and need for mechanical ventilation in acute exacerbations of chronic obstructive pulmonary disease: development and validation of a simple risk score. Arch Intern Med 2009;169:1595-602.

86. Wildman MJ, Harrison DA, Welch CA, et al. A new measure of acute physiological derangement for patients with exacerbations of obstructive airways disease: the COPD and asthma physiology score. Respir Med 2007; 101:1994-2002.

87. Kollef MH, O'Brien JD, Zuckerman GR, et al. BLEED: A classification tool to predict outcomes in patients with acute upper and lower gastrointestinal hemorrhage. Crit Care Med 1997;25:1125-32

88. Bordley DR, Mushlin Al, Dolan JG, et al. Early clinical signs identify low-risk patients with acute upper gastrointestinal hemorrhage. JAMA 1985;253:3282-5.

89. Sarwar S, Dilshad A, Khan AA, et al. Predictive value of Rockall score for rebleeding and mortality in patients with variceal bleeding. J Coll Physicians Surg Pakistan 2007:17:253-6.

90. Das A, Ben-Menachem T, Farooq FT, et al. Artificial neural network as a predictive instrument in patients with acute nonvariceal upper gastrointestinal hemorrhage. Gastroenterology 2008;134:65-74.

91. Stanley A, Ashley D, Dalton $\mathrm{H}$, et al. Outpatient management of patients with low-risk upper-gastrointestinal haemorrhage: multicentre validation and prospective evaluation. Lancet 2009;373:42-7.

92. Chen I-C, Hung M-S, Chiu T-F, et al. Risk scoring systems to predict need for clinical intervention for patients with nonvariceal upper gastrointestinal tract bleeding. Am J Emerg Med 2007;25:774-9.

93. Sanders D, Carter M, Goodchap R, et al. Prospective Validation of the Rockall Risk Scoring System for Upper GI Hemorrhage in Subgroups of Patients With Varices and Peptic Ulcers. Am J Gastroenterol 2002;97:630-5.

94. Church NI, Dallal HJ, Masson J, et al. Validity of the Rockall scoring system after endoscopic therapy for bleeding peptic ulcer: a prospective cohort study. Gastrointest Endosc 2006:63:606-12.

95. Strate LL, Saltzman JR, Ookubo R, et al. Validation of a Clinical Prediction Rule for Severe Acute Lower Intestinal Bleeding. Am J Gastroenterol 2005;100:1821-7.

96. Le Conte $\mathbf{P}$, Coutant V, N'Guyen JM, et al. Prognostic factors in acute cardiogenic pulmonary edema. Am J Emerg Med 1999;17:329-32.

97. Auble TE, Hsieh M, McCausland JB, et al. Comparison of four clinical prediction rules for estimating risk in heart failure. Ann Emerg Med 2007:50:127-35.

98. Fiutowski M, Waszyrowski T, Krzeminska-Pakula M, et al. Pulmonary edema prognostic score predicts in-hospital mortality risk in patients with acute cardiogenic pulmonary edema. Heart Lung 2008;37:46-53.

99. Lee DS, Austin PC, Rouleau JL, et al. Predicting mortality among patients hospitalized for heart failure. JAMA 2003:290:2581-7.

100. Elbaz G, Etzion 0, Delgado J, et al. Hypothermia in a desert climate: severity score and mortality prediction. Am J Emerg Med 2008;26:683-8.
101. Aronin SI, Peduzzi P, Quagliarello VJ. Community-acquired bacterial meningitis: risk stratification for adverse clinical outcome and effect of antibiotic timing. Ann Intern Med 1998;129:862-9.

102. Weisfelt M, van de Beek D, Spanjaard L, et al. A risk score for unfavorable outcome in adults with bacterial meningitis. Ann Neurol 2008;63:90-7.

103. Dutta $\mathbf{P}$, Bhansali A, Masoodi SR, et al. Predictors of outcome in myxoedema coma: a study from a tertiary care centre. Crit Care 2008;12:R1.

104. Chatzicostas C, Roussomoustakaki M, Vlachonikolis IG, et al. Comparison of Ranson, APACHE II and APACHE III scoring systems in acute pancreatitis. Pancreas 2002; $25: 331-5$

105. Singh VK, Wu BU, Bollen TL, et al. A prospective evaluation of the bedside index for severity in acute pancreatitis score in assessing mortality and intermediate markers of severity in acute pancreatitis. Am J Gastroenterol 2009:104:966-71.

106. de Beaux A, Palmer K, Carter D. Factors influencing morbidity and mortality in acute pancreatitis; an analysis of 279 cases. Gut 1995;37:121-6.

107. De Sanctis J, Lee M, Gazelle G, et al. Prognostic indicators in acute pancreatitis: CT vs APACHE II. Clin Radiol 1997:52:842-8.

108. Gürleyik G, Emir S, Kiliçoglu G, et al. Computed Tomography Severity Index, APACHE II Score, and Serum CRP Concentration for Predicting the Severity of Acute Pancreatitis. J Pancreas 2005;6:562-7.

109. Meek K, Toosie K, Stabile BE, et al. Simplified admission criterion for predicting severe complications of gallstone pancreatitis. Arch Surg 2000;135:1048-54.

110. Meek K, Virgilio C, Murrell Z, et al. Correlation between Admission Laboratory Values, Early Abdominal Computed Tomography, and Severe Complications of Gallstone Pancreatitis. Am J Surg 2000;180:556-60.

111. Papachristou GI, Papachristou DJ, Avula H, et al. Obesity increases the severity of acute pancreatitis: performance of APACHE-0 score and correlation with the inflammatory response. Pancreatology 2006;6:279-85

112. Spitzer AL, Barcia AM, Schell MT, et al. Applying Ockham's razor to pancreatitis prognostication: a four-variable predictive model. Ann Surg 2006;243:380-8.

113. van den Biezenbos A, Kruyt $\mathrm{P}$, Bosscha $\mathrm{K}$, et al. Added value of $\mathrm{CT}$ criteria compared to the clinical SAP score in patients with acute pancreatitis. Abdom Imag 1998;23:622-6.

114. Yeung YP, Lam BYK, Yip AWC. APACHE system is better than Ranson system in the prediction of severity of acute pancreatitis. HBPD Int 2006;5:294-9.

115. Garcea G, Gouda M, Hebbes C, et al. Predictors of severity and survival in acute pancreatitis: validation of the efficacy of early warning scores. Pancreas 2008;37:e54-61.

116. Taylor SL, Morgan DL, Denson KD, et al. A comparison of the Ranson, Glasgow, and APACHE II scoring systems to a multiple organ system score in predicting patient outcome in pancreatitis. Am J Surg 2005;189:219-22.

117. Ueda T, Takeyama $Y$, Yasuda T, et al. Simple scoring system for the prediction of the prognosis of severe acute pancreatitis. Surgery 2007:141:51-8.

118. Halonen KI, Leppäniemi AK, Lundin JE, et al. Predicting fatal outcome in the early phase of severe acute pancreatitis by using novel prognostic methods. Pancreatology 2003;3:309-15.

119. Gan I, May G, Raboud J, et al. Pancreatitis in HIV infection: predictors of severity. Am J Gastroenterol 2003:98:1278-83.

120. Bont J, Hak E, Hoes AW, et al. Predicting death in elderly patients with community-acquired pneumonia: a prospective validation study reevaluating the CRB-65 severity assessment tool. Arch Intern Med 2008;168:1465-8.

121. Carusone SBC, Walter SD, Brazil K, et al. Infections in nursing home residents: predictors of hospitalization and mortality. J Am Geriatr Soc 2007:55:414-19

122. Bauer T, Ewig S, Marre R, et al. CRB-65 predicts death from community-acquired pneumonia. J Intern Med 2006;260:93-101.

123. Kruger S, Papassotiriou J, Marre R, et al. Pro-atrial natriuretic peptide and pro-vasopressin to predict severity and prognosis in community-acquired pneumonia: results from the German competence network CAPNETZ. Intens Care Med 2007;33:2069-78.

124. Phua J, See K, Chan Y, et al. Validation and clinical implications of the IDSA/ATS minor criteria for severe community-acquired pneumonia. Thorax 2009;64:598-603

125. Schuetz P, Stolz D, Mueller B, et al. Endothelin-1 precursor peptides correlate with severity of disease and outcome in patients with community acquired pneumonia. BMC Infect Dis 2008;8:22.

126. Pilotto A, Addante F, Ferrucci $L$, et al. The multidimensional prognostic index predicts short- and long-term mortality in hospitalized geriatric patients with pneumonia. J Gerontol A Biol Sci Med Sci 2009;64A:880-7.

127. Yandiola PPE, Capelastegui A, Quintana J, et al. Prospective comparison of severity scores for predicting clinically relevant outcomes for patients hospitalized with community-acquired pneumonia. Chest 2009;135:1572-9.

128. Parsonage $\mathbf{M}$, Nathwani $D$, Davey $\mathrm{P}$, et al. Evaluation of the performance of CURB-65 with increasing age. Clin Microbiol Infect 2009;15:858-64.

129. Barlow G, Nathwani D, Davey P. The CURB65 pneumonia severity score outperforms generic sepsis and early warning scores in predicting mortality in community-acquired pneumonia. Thorax 2007;62:253-9.

130. Chalmers J, Singanayagam A, Murray M, et al. Risk factors for complicated parapneumonic effusion and empyema on presentation to hospital with community-acquired pneumonia. Thorax 2009;64:592-7. 
131. Charles PG, Wolfe R, Whitby M, et al. SMART-COP: a tool for predicting the need for intensive respiratory or vasopressor support in community-acquired pneumonia. Clin Infect Dis 2008;47:375-84.

132. Ewig S, de Roux A, Bauer $\mathrm{T}$, et al. Validation of predictive rules and indices of severity for community acquired pneumonia. Thorax 2004;59:421-7.

133. Lim W, van der Eerden M, Laing $\mathrm{R}$, et al. Defining community acquired pneumonia severity on presentation to hospital: an international derivation and validation study. Thorax 2003; 58:377-82.

134. Man SY, Lee N, Ip M, et al. Prospective comparison of three predictive rules for assessing severity of community-acquired pneumonia in Hong Kong. Thorax 2007:62:348-53

135. Flanders WD, Tucker G, Krishnadasan A, et al. Validation of the pneumonia severity index: importance of study-specific recalibration. J Gen Intern Med 1999;14:333-40.

136. Garau J, Baquero F, Perez-Trallero E, et al. Factors impacting on length of stay and mortality of community-acquired pneumonia. Clin Microbiol Infect 2008;14:322-9.

137. Menendez R, Martinez R, Reyes S, et al. Biomarkers improve mortality prediction by prognostic scales in community-acquired pneumonia. Thorax 2009;64:587-91.

138. Renaud B, Labarère J, Coma $\mathrm{E}$, et al. Risk stratification of early admission to the intensive care unit of patients with no major criteria of severe community-acquired pneumonia: development of an international prediction rule. Critical Care 2009;13:R54

139. Kontou P, Kuti JL, Nicolau DP. Validation of the infectious diseases society of America/American Thoracic Society criteria to predict severe community-acquired pneumonia caused by Streptococcus pneumoniae. Am J Emerg Med 2009:27:968-74

140. Angus DC, Marrie TJ, Obrosky DS, et al. Severe community-acquired pneumonia use of intensive care services and evaluation of American and British Thoracic Society diagnostic criteria. Am J Respir Crit Care Med 2002:166:717-23.

141. Challen K, Bright J, Bentley A, et al. Physiological-social score (PMEWS) vs. CURB-65 to triage pandemic influenza: a comparative validation study using community-acquired pneumonia as a proxy. BMC Health Serv Res 2007:7:33.

142. Loh L-C, Khoo S-K, Quah S-Y, et al. Adult community-acquired pneumonia in Malaysia: prediction of mortality from severity assessment on admission. Respirology 2004;9:379-86.

143. Mody L, Sun R, Bradley S. Community-acquired pneumonia in older veterans: does the pneumonia prognosis index help? J Am Geriatr Soc 2002;50:434-8.

144. Zuberi F, Khan J. Prospective comparison of prediction rules of mortality risk for CAP in a developing country. Int J Tuberc Lung Dis 2008;12:447-52.

145. Schaaf B, Kruse J, Rupp J, et al. Sepsis severity predicts outcome in community-acquired pneumococcal pneumonia. Eur Respir J 2007;30:517-24

146. Kollef KE, Reichley RM, Micek ST, et al. The Modified APACHE II score outperforms Curb65 pneumonia severity score as a predictor of 30-day mortality in patients with methicillin-resistant Staphylococcus aureus pneumonia. Chest 2008;133:363-9.

147. Valencia M, Badia JR, Cavalcanti M, et al. Pneumonia severity index class v patients with community-acquired pneumonia: characteristics, outcomes, and value of severity scores. Chest 2007:132:515-22.

148. Sanders KM, Marras TK, Chan CK. Pneumonia severity index in the immunocompromised. Can Respir J 2006;13:89-93.

149. Davies J, Eddleston M, Buckley N. Predicting outcome in acute organophosphorus poisoning with a poison severity score or the Glasgow coma scale. $0 \mathrm{~J}$ Med 2008; 101:371-9.

150. Eizadi-Mood N, Saghaei M, Jabalameli M. Predicting outcomes in organophosphate poisoning based on APACHE II and modified APACHE II scores. Hum Exp Toxicol 2007:26:573-8.

151. Aujesky D, Obrosky DS, Stone RA, et al. A prediction rule to identify low-risk patients with pulmonary embolism. Arch Intern Med 2006;166:169-75.

152. Palmieri V, Gallotta G, Rendina D, et al. Troponin I and right ventricular dysfunction for risk assessment in patients with nonmassive pulmonary embolism in the Emergency Department in combination with clinically based risk score. Intern Emerg Med 2008;3:131-8.

153. Choi W-H, Kwon SU, Jwa YJ, et al. The Pulmonary Embolism Severity Index in Predicting the Prognosis of Patients With Pulmonary Embolism. Kor J Intern Med 2009:24:123-7.

154. Shapiro NI, Wolfe RE, Moore RB, et al. Mortality in emergency department sepsis (MEDS) score: a prospectively derived and validated clinical prediction rule. Crit Care Med 2003;31:670-5

155. Howell MD, Donnino M, Talmor D, et al. Performance of severity of illness scoring systems in Emergency Department patients with infection. Acad Emerg Med 2007; 14:709-14

156. Sankoff JD, Goyal M, Gaieski DF, et al. Validation of the mortality in emergency department sepsis (MEDS) score in patients with the systemic inflammatory response syndrome (SIRS). Crit Care Med 2008;36:421-6.

157. Kofoed K, Eugen-Olsen J, Petersen J, et al. Predicting mortality in patients with systemic inflammatory response syndrome: an evaluation of two prognostic models, two soluble receptors, and a macrophage migration inhibitory factor. Eur J Clin Microbiol Infect Dis 2008:27:375-83.

158. Vorwerk C, Loryman B, Coats $\mathrm{T}$, et al. Prediction of mortality in adult emergency department patients with sepsis. Emerg Med J 2009;26:254-8.
159. Lee C-C, Chen S-Y, Tsai C-L, et al. Prognostic value of mortality in emergency department sepsis score, procalcitonin, and C-reactive protein in patients with sepsis at the emergency department. Shock 2008;29:322-7.

160. Jones AE, Saak K, Kline JA. Performance of the Mortality in emergency department sepsis score for predicting hospital mortality among patients with severe sepsis and septic shock. Am J Emerg Med 2008:26:689-92.

161. Chu VH, Cabell CH, Benjamin DK, et al. Early Predictors of in-hospital death in infective endocarditis. Circulation 2004;109:1745-9.

162. Yilmazlar T, Ozturk E, Alsoy A, et al. Necrotizing soft tissue infections: Apache I score, dissemination, and survival. World J Surg 2007;31:1858-62.

163. Hsieh C-B, Tzao C, Yu C-Y, et al. APACHE II score and primary liver cancer history had risk of hospital mortality in patients with pyogenic liver abscess. Digest Liver Dis 2006;38:498-502.

164. Chen S-C, Huang C-C, Tsai S-J, et al. Severity of disease as main predictor for mortality in patients with pyogenic liver abscess. Am J Surg 2009;198:164-72.

165. Nguyen HB, Banta JE, Cho TW, et al. Mortality predictions using current physiological scoring systems in patients meeting criteria for early goal-directed therapy and the severe sepsis resuscitation bundle. Shock 2008;30:23-8.

166. Chen C-C, Chong C-F, Liu Y-L, et al. Risk stratification of severe sepsis patients in the emergency department. Emerg Med J 2006:23:281-5.

167. Stawicki SP, Brooks A, Bilski T, et al. The concept of damage control: extending the paradigm to emergency general surgery. Injury 2008;39:93-101.

168. Neary W, Prytherch D, Foy $C$, et al. Comparison of different methods of risk stratification in urgent and emergency surgery. Br J Surg 2007;94:1300-5.

169. Egberts J-H, Summa B, Schulz U, et al. Impact of preoperative physiological risk profile on postoperative morbidity and mortality after emergency operation of complicated peptic ulcer disease. World J Surg 2007;31:1449-57.

170. Ertan T, Yoldas 0, Kýlýc YA, et al. External validation of prognostic models among cancer patients undergoing emergency colorectal surgery. Am J Surg 2008; 195:439-41.

171. Poon JT, Chan B, Law WL. Evaluation of P-POSSUM in Surgery for Obstructing Colorectal Cancer and Correlation of the Predicted Mortality With Different Surgical Options. Dis Colon Rectum 2005:48:493-8.

172. Horiuchi A, Watanabe $Y$, Doi T, et al. Evaluation of prognostic factors and scoring system in colonic perforation. World J Gastroenterol 2007;13:3228-31.

173. Anwar MA, D'Souza F, Coulter R, et al. Outcome of acutely perforated colorectal cancers: experience of a single district general hospital. Surg Oncol 2006;15:91-6.

174. Oomen J, Engel A, Cuesta M. Mortality after acute surgery for complications of diverticular disease of the sigmoid colon is almost exclusively due to patient related factors. Colorectal Dis 2006;8:112-19.

175. Mäkelä JT, Kiviniemi H, Laitinen S. Prognostic factors of perforated sigmoid diverticulitis in the elderly. Digest Surg 2005;22:100-6.

176. Notash AY, Salimi J, Rahimian H, et al. Evaluation of Mannheim peritonitis index and multiple organ failure score in patients with peritonitis. Indian J Gastroenterol 2005;24:197-200

177. Kulkarni SV, Naik AS, Subramanian N. APACHE-II scoring system in perforative peritonitis. Am J Surg 2007;194:549-52.

178. Biondo S, Ramos E, Fraccalvieri D, et al. Comparative study of left colonic Peritonitis Severity Score and Mannheim Peritonitis Index. Br J Surg 2006;93:616-22.

179. Cosgriff TM, Kelly A-M, Kerr D. External validation of the San Francisco Syncope Rule in the Australian context. Can J Emerg Med 2007:9:157-61.

180. Del Rosso A, Ungar A, Maggi R, et al. Clinical predictors of cardiac syncope at initial evaluation in patients referred urgently to a general hospital: the EGSYS score. Heart 2008:94:1620-6.

181. Hing R, Harris R. Relative utility of serum troponin and the OESIL score in syncope. Emerg Med Australas 2005:17:31-8.

182. Birnbaum A, Esses D, Bijur $P$, et al. Failure to validate the San Francisco syncope rule in an independent emergency department population. Ann Emerg Med 2008;52:151-9.

183. Sun BC, Mangione CM, Merchant G, et al. External validation of the San Francisco syncope rule. Ann Emerg Med 2007;49:420-7.

184. Johnston SC, Rothwell PM, Nguyen-Huynh MN, et al. Validation and refinement of scores to predict very early stroke risk after transient ischaemic attack. Lancet 2007;369:283-92.

185. Bray JE, Coughlan K, Bladin C. Can the ABCD Score be dichotomised to identify high-risk patients with transient ischaemic attack in the emergency department? Emerg Med J 2007:24:92-5

186. Sciolla R, Melis F. Rapid Identification of High-Risk Transient Ischemic Attacks Prospective Validation of the ABCD Score. Stroke 2008;39:297-302

187. Ay H, Arsava EM, Johnston SC, et al. Clinical- and imaging-based prediction of stroke risk after transient ischemic attack: the CIP model. Stroke 2009:40:181-6.

188. Tsivgoulis G, Spengos K, Manta $P$, et al. Validation of the ABCD score in identifying individuals at high early risk of stroke after a transient ischemic attack Stroke 2007; 37:2892-7.

189. Goodacre S, Turner J, Nicholl J. Prediction of mortality among emergency medical admissions. Emerg Med J 2006;23:372-5.

190. van der Wulp I, Schrijvers A, van Stel H. Predicting admission and mortality with the Emergency Severity Index and the Manchester Triage System: a retrospective observational study. Emerg Med J 2009;26:506-9. 
191. Baumann MR, Strout TD. Triage of geriatric patients in the emergency department: validity and survival with the emergency severity index. Ann Emerg Med 2007:49:234-40.

192. Olsson T, Lind L. Comparison of the rapid emergency medicine score and APACHE II in nonsurgical Emergency Department patients. Acad Emerg Med 2003;10:1040-8

193. Olsson T, Terent A, Lind L. Rapid Emergency Medicine score: a new prognostic tool for in-hospital mortality in nonsurgical emergency department patients. $J$ Intern Med 2004:255:579-87.

194. Masaoka T, Suzuki H, Hori S, et al. Blatchford scoring system is a useful scoring system for detecting patients with upper gastrointestinal bleeding who do not need endoscopic intervention. J Gastroenterol Hepatol 2007:22:1404-8.

195. Romagnuolo J, Barkun AN, Enns R, et al. simple clinical predictors may obviate urgent endoscopy in selected patients with nonvariceal upper gastrointestinal tract bleeding. Arch Intern Med 2007;167:265-70.

196. Cosentini R, Folli C, Cazzaniga M, et al. Usefulness of simplified acute physiology score II in predicting mortality in patients admitted to an emergency medicine ward. Intern Emerg Med 2009;4:241-7.

197. Duckitt R, Buxton-Thomas R, Walker J, et al. Worthing physiological scoring system: derivation and validation of a physiological early-warning system for medical admissions. An observational, population-based single-centre study. $\mathrm{Br} \mathrm{J}$ Anaesth 2007:98:769-74.

198. Kellett J, Deane B. The Simple Clinical Score predicts mortality for 30 days after admission to an acute medical unit. $0 \mathrm{~J}$ Med 2006;99:771-81.

199. Kellett J, Deane B, Gleeson M. Derivation and validation of a score based on Hypotension, Oxygen saturation, low Temperature, ECG changes and Loss of independence (HOTEL) that predicts early mortality between $15 \mathrm{~min}$ and $24 \mathrm{~h}$ after admission to an acute medical unit. Resuscitation 2008:78:52-8.

200. Paterson R, MacLeod D, Thetford D, et al. Prediction of in-hospital mortality and length of stay using an early warning scoring system: clinical audit. Clin Med 2006;6:281-4.

201. Cooke MW, Jinks S. Does the Manchester triage system detect the critically ill? J Accid Emerg Med 1999;16:179-81.

202. Rodriguez RM, Wang NE, Pearl RG. Prediction of poor outcome of intensive care unit patients admitted from the emergency department. Crit Care Med 1997;25:1801-6.

203. Jones AE, Fitch MT, Kline JA. Operational performance of validated physiologic scoring systems for predicting in-hospital mortality among critically ill emergency department patients. Crit Care Med 2005;33:974-8.

204. Alemi F, Rice J, Hankins R. Predicting in-hospital survival of myocardial infarction: a comparative study of various severity measures. Med Care 1990;28:762-75.

205. Gale C, Manda S, Weston C, et al. Evaluation of risk scores for risk stratification of acute coronary syndromes in the Myocardial Infarction National Audit Project (MINAP) database. Heart 2009;95:221-7.

206. Durairaj L, Reilly B, Das K, et al. Emergency department admissions to inpatient cardiac telemetry beds: a prospective cohort study of risk stratification and outcomes. Am J Med 2001:110:7-11.

207. Hollander JE, Sites FD, Pollack CV, et al. Lack of utility of telemetry monitoring for identification of cardiac death and life-threatening ventricular dysrhythmias in low-risk patients with chest pain. Ann Emerg Med 2004:43:71-6.

208. Williams B, Wright R, Murphy J, et al. A new simplified immediate prognostic risk score for patients with acute myocardial infarction. Emerg Med J 2006;23:186-92.

209. Normand S-LT, Glickman ME, Sharma R, et al. Using admission characteristics to predict short-term mortality from myocardial infarction in elderly patients: results from the cooperative cardiovascular project. JAMA 1996;275:1322-8.
210. Christiansen JP, Liang C-s. Reappraisal of the Norris Score and the prognostic value of left ventricular ejection fraction measurement for in-hospital mortality afte acute myocardial infarction. Am J Cardiol 1999;83:589-91.

211. Das R, Dorsch $\mathrm{M}$, Lawrance $\mathrm{R}$, et al. External validation, extension and recalibration of Braunwald's simple risk index in a community-based cohort of patients with both STEMI and NSTEMI. Int J Cardiol 2006;107:327-32.

212. Bradshaw PJ, Ko DT, Newman AM, et al. Validation of the Thrombolysis In Myocardial Infarction (TIMI) risk index for predicting early mortality in a population-based cohort of STEMI and non-STEMI patients. Can J Cardiol 2007;23:51-6.

213. Gralnek IM, Dulai GS. Incremental value of upper endoscopy for triage of patients with acute non-variceal upper-Gl hemorrhage. Gastrointest Endosc 2004:60:9-14.

214. Buising KL, Thursky KA, Black JF, et al. Reconsidering what is meant by severe pneumonia: a prospective comparison of severity scores for community acquired pneumonia. Thorax 2006;61:419-24

215. Feldman C, Alanee S, Yu V, et al. Severity of illness scoring systems in patients with bacteraemic pneumococcal pneumonia: implications for the intensive care unit care. Clin Microbiol Infect 2009;15:850-7.

216. Buising KL, Thursky KA, Black JF, et al. Identifying severe community-acquired pneumonia in the emergency department: a simple clinical prediction tool. Emerg Med Australas 2007;19:418-26.

217. Capelastegui A, Espana $\mathrm{P}$, Quintana J, et al. Validation of a predictive rule for the management of community-acquired pneumonia. Eur Respir J 2006:27:151-7.

218. Aujesky D, Auble TE, Yealy DM, et al. Prospective comparison of three validated prediction rules for prognosis in community-acquired pneumonia. Am J Med 2005; 118:384-92.

219. España PP, Capelastegui A, Gorordo I, et al. Development and Validation of a Clinical Prediction Rule for Severe Community-acquired Pneumonia. Am J Respir Crit Care Med 2006;174:1249-56.

220. Chalmers JD, Singanayagam A, Scally C, et al. Admission D-dimer can identify low-risk patients with community-acquired pneumonia. Ann Emerg Med 2009; 53:633-8

221. Huang DT, Weissfeld LA, Kellum JA, et al. Risk prediction with procalcitonin and clinical rules in community-acquired pneumonia. Ann Emerg Med 2008;52:48-58.

222. Huang DT, Angus DC, Kellum JA, et al. Midregional proadrenomedullin as a prognostic tool in community-acquired pneumonia. Chest 2009;136:823-31.

223. Querol-Ribelles JM, Tenias JM, Grau E, et al. Plasma d-Dimer levels correlate with outcomes in patients with community-acquired pneumonia. Chest 2004:126:1087-92.

224. Man SY, Chan KM, Wong FY, et al. Evaluation of the performance of a modified Acute Physiology and Chronic Health Evaluation (APACHE II) scoring system for critically ill patients in emergency departments in Hong Kong. Resuscitation 2007;74:259-65.

225. Cattermole GN, Mak SP, Liow CE, et al. Derivation of a prognostic score for identifying critically ill patients in an emergency department resuscitation room. Resuscitation 2009;80:1000-5.

226. Ohman EM, Granger CB, Harrington RA, et al. Risk stratification and therapeutic decision making in acute coronary syndromes. JAMA 2000;284:876-8.

227. Gao H, McDonnell A, Harrison DA, et al. Systematic review and evaluation of physiological track and trigger warning systems for identifying at-risk patients on the ward. Intens Care Med 2007;33:667-9.

228. Smith GB, Prytherch DR, Schmidt PE, et al. A review, and performance evaluation of single-parameter "track and trigger" systems. Resuscitation 2008;79:11-21.

229. Smith GB, Prytherch DR, Schmidt PE, et al. Review and performance evaluation of aggregate weighted 'track and trigger' systems. Resuscitation 2008;77:170-9. 